\title{
Immunomodulation by gadolinium chloride-induced Kupfer cell phagocytosis blockade
}

\author{
G. Lázár ${ }^{\mathrm{a}, *}$, E. Husztik ${ }^{\mathrm{a}}$, G. Lázár, Jr.', I. Kiss ${ }^{\mathrm{a}}$, J. Oláh ${ }^{\mathrm{c}}$, J. Szakács ${ }^{\mathrm{a}}$ \\ ${ }^{a}$ Institute of Pathophysiology, Albert Szent-Györgyi Medical University, PO Box 531, 6701 Szeged, Hungary \\ ${ }^{\mathrm{b}}$ Department of Surgery, Albert Szent-Györgyi Medical University, PO Box 531, 6701 Szeged, Hungary \\ ${ }^{\mathrm{c}}$ Department of Dermatology, Albert Szent-Györgyi Medical University, PO Box 531, 6701 Szeged, Hungary
}

\begin{abstract}
Gadolinium chloride $\left(\mathrm{GdCl}_{3}\right)$, a rare earth metal salt, depresses macrophage activity, and is commonly used to study the physiology of the reticuloendothelial system. In the present work, the effect of $\mathrm{GdCl}_{3}$-induced Kupffer cell blockade on the humoral immune response in mice to sheep red blood cells (SRBC) was investigated. Kupffer cell phagocytosis blockade was found to increase both the primary and secondary immune responses to SRBC. The primary immune response was significantly augmented in animals injected intravenously with $\mathrm{GdCl}_{3}$ 2, 3 or 4 days before injection of the cellular antigen, but $\mathrm{GdCl}_{3}$ injected 7 days before the antigen did not modify the immune response. Increased secondary humoral immune responses were also observed. When $\mathrm{GdCl}_{3}$ was injected 2 days before the second dose of antigen, the numbers of both IgM and IgG-producing plaque forming cells were augmented. $\mathrm{GdCl}_{3}$ injected 2 days before the first dose of SRBC did not modify the humoral immune response. Earlier studies with ${ }^{51} \mathrm{Cr}$-labelled foreign red blood cells suggested that the augmentation of the humoral immune response in $\mathrm{GdCl}_{3}$-pretreated mice is a consequence of the spillover of the antigen from the liver into the spleen and other extrahepatic reticuloendothelial organs. (C) 1998 Elsevier Science S.A.
\end{abstract}

Keywords: Gadolinium chloride; Humoral immune response; IgG; IgM; Immunomodulation; Kupffer cell; Phagocytosis blockade

\section{Introduction}

The Kupffer cells, the resident macrophages of the liver, comprise the largest population of macrophages in the body. Besides their endocytic capacity, the Kupffer cells can synthesise and excrete highly reactive materials, such as the superoxide anion, hydrogen peroxide, nitric oxide, eicosanoids, peptide mediators and proteolytic enzymes [1]. It has been reported that the Kupffer cell blockade induced by $\mathrm{GdCl}_{3}$ inhibits the secretion of these active substances and decreases the liver-damaging effects of several hepatotoxins [2,3], the liver damage induced by ischaemia-reperfusion [4] and the development of lethal endotoxin shock [5]. Recent studies demonstrated that the Kupffer cell blockade induced by $\mathrm{GdCl}_{3}$ inhibits mouse anaphylaxis [6], the hypotension induced by immunoglobulin aggregates [7], and the induction of tolerance to portal venous antigen [8].

The roles of Kupffer cells in the aspecific resistance of the organism are well known. Kupffer cells, the resident macrophages of the liver, have been shown to express class

\footnotetext{
*Corresponding author: Tel.: +36 62310651 ; fax: +36 62455695 ; e-mail: lazar@pathph.szote.u-szeged.hu
}

II antigens of the major histocompatibility complex and to have the capacity for antigen presentation in vitro, but their regulatory roles in the induction and expression of immune response in vivo have not been well defined. Our recent studies [9] show that Kupffer cell blockade induced by $\mathrm{GdCl}_{3}$ prolongs the survival of human insulinoma cell xenograft implanted into the liver, which suggests that the Kupffer cells may play significant roles in the recognition or/and rejection of xenograft. In the present study, the effects of Kupffer cell phagocytosis blockade induced by $\mathrm{GdCl}_{3}[10,11]$ were investigated on the humoral immune responses in mice to sheep red blood cells (SRBC).

\section{Materials and methods}

\subsection{Animals}

Male CFLP mice (Animal House, Gödöllõ, Hungary) weighing $30-35 \mathrm{~g}$ were used.

\subsection{Kupffer cell blockade}

Kupffer cell phagocytosis blockade [10,11] was induced with $\mathrm{GdCl}_{3}$ (Prolabo, France). $\mathrm{GdCl}_{3}$ was dissolved in 
$0.85 \%$ saline and injected intravenously at a dose of $0.5 \mathrm{mg} / 100 \mathrm{~g}$ body weight.

\subsection{Humoral immune response}

For the primary immune response, mice were injected intravenously with $10^{7} \mathrm{SRBC}$. For the secondary immune response, animals were inoculated with the same dosage of SRPC 14 days after the primary injection. On the fourth day following SRBC immunisation, the mice were killed, the spleens were removed and the cells were dissociated by pressing through a 50-mesh stainless-steel screen. To assay humoral immune responses, the number of haemolytic plaque forming cells was determined [12] or the amount of antibody production was quantitated by the haemolytic antibody isotope release assay [13]. To measure IgG responses, heat-inactivated rabbit anti-mouse IgG monoclonal facilitating antibodies were utilised.

\subsection{Statistics}

Results were evaluated biometrically with the Student t-test and the Tukey Studentized range test.

\section{Results}

The Kupffer cell phagocytosis blockade was found to increase the humoral immune responses to SRBC.

The primary immune response to SRBC was significantly augmented in the groups of animals injected intravenously with $\mathrm{GdCl}_{3} 1,2,3$ or 4 days before injection of the cellular antigen, but $\mathrm{GdCl}_{3}$ injected 7 days before the antigen injection did not influence the humoral immune response (Fig. 1).

An increased secondary humoral immune response was

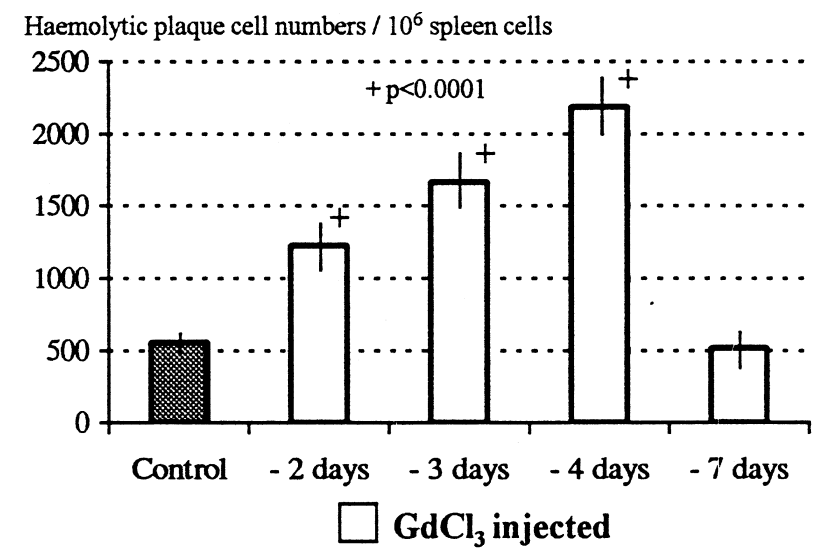

Fig. 1. Effect of $\mathrm{GdCl}_{3}$ on the primary immune response to sheep red blood cells. Mice received $10^{7}$ sheep red blood cells 2, 3, 4 or 7 days following $\mathrm{GdCl}_{3}$ treatment. The number of plaque forming cells in the spleens was determined on the fourth day after the injection of antigen.

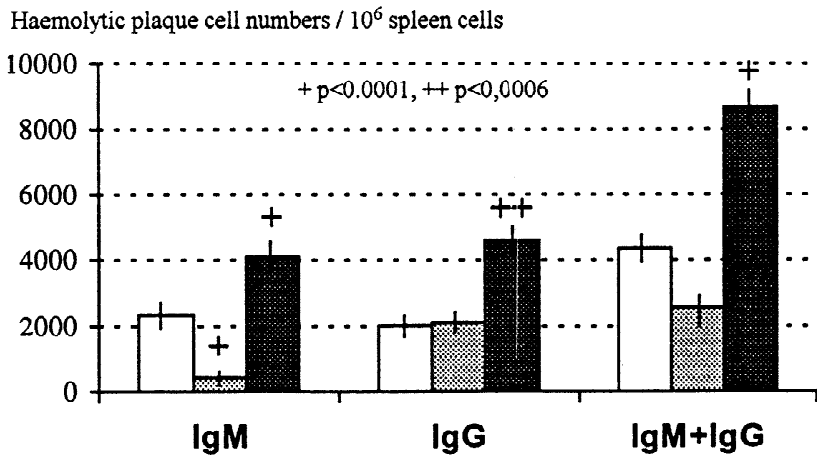

口CONTROL

$\mathrm{GdCl}_{3}$ was injected 2 days before the first injection of $10^{7} \mathrm{SRBC}$

$\mathrm{GdCl}_{3}$ was injected 2 days before the second injection of $10^{7} \mathrm{SRBC}$

Fig. 2. Effect of $\mathrm{GdCl}_{3}$ on the secondary immune response to sheep red blood cells. Mice received $10^{7}$ sheep red blood cells on the first and fourteenth days of the experiments. $\mathrm{GdCl}_{3}$ was given 2 days before the first or second dose of antigen. The number of IgM- or IgG-producing plaque forming cells in the spleens was measured on the fourth day following the second injection of the antigen.

also observed. When $\mathrm{GdCl}_{3}$ was injected 2 days before the second dose of antigen, the numbers of both IgM- and IgG-producing plaque forming cells were augmented. $\mathrm{GdCl}_{3}$ injected 2 days before the first dose of SRBC did not modify the humoral immune response (Fig. 2).

The results of the haemolytic antibody isotope release assay (not shown) directly correlated with the number of antibody-producing cells measured by the conventional plaque assay.

\section{Discussion}

Kupffer cells normally serve as an effective filter, removing blood-borne particulate matter and gut-derived antigens from the portal circulation. The present studies clearly reveal that the Kupffer cell phagocytosis blockade induced by $\mathrm{GdCl}_{3}$ increases both the primary and the secondary humoral immune responses. Several studies have demonstrated that not only is the bulk of the intravenously injected particulate matter taken up by the Kupffer cells, but the functional state of these cells strongly influences the distribution of such particulate matter among the organs of the reticuloendothelial system. Our earlier studies $[11,14]$ with ${ }^{51} \mathrm{Cr}$-labelled foreign red blood cells clearly showed that $\mathrm{GdCl}_{3}$, while depressing the uptake of foreign red blood cells in the liver, increases it in the extrahepatic organs. Those experiments suggest that the augmentation of humoral immune response in $\mathrm{GdCl}_{3}$-pretreated mice may be a consequence of the spillover of the antigen from the liver into the spleen and other extrahepatic reticuloendothelial organs.

Cytokines are known [15] to have a powerful immunostimulatory effect. On the other hand, $\mathrm{GdCl}_{3}$ pretreatment 
significantly increases the bacterial lipopolysaccharide-induced tumour necrosis factor production by the spleen [14]. These results support the finding that the $\mathrm{GdCl}_{3}$ induced Kupffer cell phagocytosis blockade leads to activation of the spleen and may explain some of the immunological effects of $\mathrm{GdCl}_{3}$.

\section{Acknowledgements}

This work was supported by the Hungarian National Science Foundation (OTKA, grant Nos. TO 12963, 17621, 23638) and the Council of Medical Science of the Hungarian Ministry of Welfare (ETT, 1997).

\section{References}

[1] K. Decker, Eur. J. Biochem. 192 (1990) 196

[2] C. Barriault, M. Audet, I.M. Yousef, B. Tuchweber, Toxicol. Appl. Pharmacol. 131 (1995) 206.
[3] G. Lázár, D. Serra, B. Tuchweber, Toxicol. Appl. Pharmacol. 29 (1973) 367.

[4] S. Suzuki, L.H. Toledo-Pereyra, F. Ridriguez, F. Lopez, Circ. Shock 42 (1994) 204.

[5] Y. Iimuro, M. Yamamoto, H. Kohno, J. Itakura, H. Fujii, Y. Matsumoto, J. Leukocyte Biol. 55 (1994) 723.

[6] G. Lázár Jr., G. Lázár, J. Kaszaki, J. Oláh, I. Kiss, E. Husztik, Agents and Actions 41 (1994) C97.

[7] B. Jenei, G. Lázár, K. Bartha, G.A. Medgyesi, Agents and Actions 32 (1991) 333.

[8] C.R. Roland, M.J. Maningo, B.F. Duffy, M.W. Flye, Transplantation 55 (1993) 1151.

[9] G. Lázár Jr., G. Farkas, J. Csanádi, G. Lázár, Transplantation 63 (1997) 729.

[10] G. Lázár, J. Reticuloendothel. Soc. 13 (1973) 231.

[11] E. Husztik, G. Lázár, Á. Párducz, Br. J. Exp. Pathol. 61 (1980) 624.

[12] N.K. Jerne, A.A. Nordin, Science 140 (1963) 405.

[13] L. Baecher-Steppan, N.I. Kerkvliet, Clin. Exp. Immunol. 44 (1981) 440.

[14] G. Lázár Jr., G. Lázár, J. Oláh, E. Husztik, E. Duda, J. Alloys Comp. 225 (1995) 623.

[15] M. Ballow, S. Xiang, W. Wang, L. Brodsky, J. Clin. Immunol. 16 (1996) 171. 